\title{
KISAH RELIEF FAUNA PADA CANDI BOROBUDUR
}

\author{
Oleh: Riky Febrianto*, Muhamad Idris** \\ *Mahasiswa Program Studi Pendidikan Sejarah FKIP Universitas PGRI Palembang \\ ${ }^{*}$ Dosen Program Studi Pendidikan Sejarah FKIP Universitas PGRI Palembang
}

\begin{abstract}
ABSTRAK
Relief candi Borobudur menyimpan data keanekaragaman fauna dalam kebudayaan Mataram kuno. Data kesejarahan tersebut belum dimanfaatkan dalam pembelajaran sejarah. Permasalahan penelitian: nilai sejarah apakah dari relief fauna di candi Borobudur yang dapat dijadikan sumber pembelajaran sejarah?. Tujuan penelitian: 1) Mengetahui nilai sejarah dan nilai moral relief fauna di candi Borobudur; 2) Mengetahui pemanfaatan relief fauna sebagai sumber pembelajaran sejarah. Metode penelitian yang digunakan metode deskriptif kualitatif. Jenis data: dokumen, observasi, wawancara. Teknik pengumpulan data: dokumentasi, observasi lapangan, wawancara mendalam, dengan menggunakan teknik triangulasi data dan sumber. Teknik analisis data model interaktif. Pembahasan relief fauna pada dinding candi Borobudur merekam data keanekaragaman hayati fauna Indonesia dan India yang ada dalam kebudayaan Jawa pada abad 9-11 Masehi. Ditemukan 24 jenis fauna yang diabadikan pada relief candi Borobudur. Relief fauna di dinding candi Borobudur mengandung nilai sejarah, nilai budaya, dan juga nilai moral dalam kehidupan sehari-hari yang bisa diterapkan dalam kehidupan sekarang ini.
\end{abstract}

Kata Kunci: Relief Fauna, Kebudayaan Mataram Kuno.

\section{A. PENDAHULUAN}

Candi Borobudur dibangun antara 780 Masehi oleh dua raja Sailendra: Wisnu dan Samaratungga, makna dari namanya diturunkan dari "Bhumi Sambharabhhaudara" yang berarti: gunung kumpulan kebajikan pada tahap (menjadi Bodhisattva). Monumen ini tampaknya telah disebutkan pada prasasti yang berangka tahun 842 Masehi, tercatat sebuah pendukung berdirinya sebuah pertapaan yang bernama Bhumisambhara (Munoz, 2013:502).

Candi Borobudur adalah mahakarya putra Nusantara yang telah diakui dunia, sebagaimana pengakuan UNESCO. Candi ini merupakan candi agama Buddha terbesar di pulau Jawa. Dari sisi letaknya lokasi ini dipilih berdasarkan pertimbangan seperti secara simbolis, Borobudur berdekatan dengan pertemuan dua sungai, yaitu sungai Elo dan sungai Prago, yang berorientasi ke dua sungai suci di India, yaitu sungai Yamuna dan sungai Gangga. Di pertemuan kedua sungai tersebut didirikan bangunan-bangunan suci (Haryono, 2011:1). Dari segi agama Borobudur adalah perpaduan Buddha Mahayana dengan Tatrayana, dengan meditasi filsafat Yogacara. Bentuk agama Buddha semacam ini mirip dengan agama Buddha yang berkembang di Bengal India, pada waktu pemerintahan raja-raja Pala pada sekitar abad ke VIII. Candi Borobudur secara keseluruan sangat istimewa, baik dalam hal ukuran, teknik penyusunan batu, dan segi pemahatan relief dalam hal kualitas maupun kuantitasnya, pemilihan jenis-jenis cerita, maupun arca-arcanya. Candi Borobudur terdiri atas 10 tingkatan, enam tingkatan bawah berdenah bujur sangkar dengan ukuran makin keatas makin kecil, dengan tingkat $7,8,9$, berdenah hampir bulat, diakhiri stupa puncak yang besar. Alas bangunan candi tidak berhias relief sama sekali, kecuali bingkai-bingkai yang sangat bagus dan ternyata bagian ini adalah tutup atau pelapis dari bagian kaki bangunan yang memiliki relief cerita Karmawibhanga. Di 
atas alas bangunan terdapat lima teras yang masing-masing memiliki pagar langkan, sehingga membentuk lima lorong di sekeliling candi, yang satu di atas yang lain. Tiga teras hampir bulat terletak di atasnya, dan tiga berhias relief, tetapi sebagai gantinya dibangun stupa-stupa berterawang, mengelilingi stupa puncak yang sangat besar. Secara keseluruhan candi Borobudur berbentuk stupa, tetapi mempunyai struktur berundak teras (Depbikbud, 2013:100).

Candi Borobudur terletak di pusat jantung pulau Jawa, dengan puncaknya yang menjulang ke angkasa dikelilingi bukit Menoreh yang membujur dari arah Timur ke Barat dan gunung-gunung berapi seperti Merapi dan Merbabu di sebelah Timur, Sumbing dan Sindoro di sebelah Barat, dan pemandangan yang hijau indah membentang sejauh mata memandang. Kesemuanya itu menimbulkan suasana tenang, aman, dan tentram (Soetarno, 2003:71). Adapun yang menjadi raja Mataram kuno dari dinasti Syailendra adalah Samaratungga, ia adalah penganut agama Buddha Mahayana. Raja Samaratungga ini mempunyai karya monumental, yaitu candi Borobudur. Samaratungga berperan menjadi pengatur segalah dimensi kehidupan rakyat (Purwadi, 2007:21).

Bangunan klasik Hindu dan Buddha di Jawa berkembang pesat, hal tersebut terbukti dengan banyaknya tinggalan yang bersifat monumental. Candi yang tersebar dari daerah Dieng (Wonosobo), Magelang. Di Yogyakarta dan Klaten, banyak yang merupakan candi-candi besar dan raya dengan aneka hiasan. Bangunan tersebut menurut beberapa arkeolog merupakan bangunan yang berfungsi sebagai candi pemujaan. Bangunanan masa klasik tersebut dibangun secara besar-besaran pada abad VII-X Masehi. Bangunan tersebut dimulai dari daerah Jawa Tengah, yang kemudian diteruskan ke Jawa Timur pada abad X-XV Masehi. Mengenal perpindahan ke Jawa Timur, disebabkan karena bencana alam letusan gunung Merapi (Siddhayatra, 1996:10).

\section{B. METODE PENELITIAN}

Metode penelitian merupakan cara yang digunakan oleh peneliti dalam mengumpulkan data penelitiannya. Seperti sudah dijelaskan, variasi dimaksud yaitu: angket, wawancara, pengamatan atau observasi, tes, dokumentasi (Arikunto, 2013:203). Metode penelitian kualitatif dinamakan sebagai metode baru, karena popularitasnya belum lama, dinamanakan postpositivistik karena berlandaskan pada filsafat postpositivisme. Metode ini disebut dengan metode interpretif karena data hasil penelitian lebih berkenaan dengan interprestasi terhadap data yang ditemukan di lapangan (Sugiyono, 2013:13-14).

Dalam penulisan skripsi ini peneliti menggunakan metode penelitian deskriptif kualitatif, yang menggunakan cara mengumpulkan sumber-sumber secara sistematis dan menggunakan sumber data secara mendalam. Penelitian deskriptif kualitatif diuraikan dengan kata-kata menurut apa adanya sesuai dengan pertanyaan penelitiannya, kemudian dianalisis dengan kata-kata apa yang melatarbelakangi responden berperilaku (berpikir, berperasaan, dan bertindak) seperti itu tidak seperti lainnya, direduksi, ditriangulasi, disimpulkan (diberi makna oleh peneliti), dan diverifikasi (dikonsultasikan kembali kepada responden dan teman sejawat). Minimal ada tiga hal yang digambarkan dalam penelitian kualitatif, yaitu karakteristik pelaku, kegiatan, atau kejadian-kejadian yang terjadi selama penelitian, dan keadaan lingkungan atau karakteristik tempat penelitian berlangsung (Usman, 2014:130). Penelitian kualitatif adalah penelitian yang menekankan pada quality atau hal yang terpenting dari sifat atau barang. Hal terpenting dari suatu barang atau jasa berupa kejadian/fenomena/gejala 
sosial adalah makna dibalik kejadian tersebut yang dapat dijadikan pelajaran berharga bagi suatu pengembangan konsep teori (Komariah, 2014:22).

\section{HASIL DAN PEMBAHASAN}

Candi peninggalan dinasti Syailendra yang berkuasa di Jawa Tengah pada abad ke VIII Masehi. Bahan yang digunakan untuk bangunan candi seluruhnya menggunakan batu andesit dengan porositas yang rapat (halus). Bangunan yang berlatar agama Budha berlantai empat ini, di setiap lantainya dihiasi dengan relief keagamaan. Lantai satu mengisahkan cerita Lalita-Awadana, Iantai 2 Gandawyuha, lantai tiga Maitreya, dan lantai 4 Samantabadra. Semua cerita tersebut secara garis besar mengisahkan perjalanan sang Budha Gautama dari sejak kecil, dewasa, dan mengajarkan keyakinan sang Budha. Pada bagian kaki candi paling bawah dan belum banyak diketahui oleh wisatawan, karena sebagian masih di tutup dengan tanah, adalah sebuah misteri cerita Maha Karrmawibhangga. Mengisahkan perjalanan perbuatan kehidupan manusia di bumi yang berisikan tentang hukum sebab akibat atau yang dikenal dengan hukum karma. Setiap perbuatan yang dilakukan di bumi baik perbuatan baik maupun kejahatan, kelak akan diterimanya di akhirat. Oleh karena itu, dengan melihat dan menghayati ajaran dalam gambar relief tersebut menjadi kontrol setiap tindakan manusia selama hidupnya di bumi. Dari seluruh adegan dalam panil-panil relief dari lantai satu sampai dengan empat, sangat dengan cerita yang menggambarkan kehidupan masyarakat, seperti alat-alat trasportasi, perahu, gerobak, kuda, gajah dan masih banyak lagi yang lainnya (Berkala Arkeologi Volume 32 No 1 Mei 2012:19-20).

Candi Borobudur adalah sebuah bangunan yang megah peninggalan agama Budha yang menjadi salah satu kebanggaan bangsa Indonesia. Tata bangunan candi Borobudur merupakan perpaduan antara budaya India dan hasil budaya Indonesia asli zaman megalithikum. Perpaduan itu terbukti dengan adanya bangunan punden berundak pada candi Borobudur yang telah bercampur dengan unsur bangunan Budha Mahayana yang berupa stupa. Selanjutnya candi Borobudur merupakan bukti sejarah kebudayaan Jawa kuno yang penting, karena relief candi Borobudur merupakan adegan abadi 'perwujudan sejarah kebudayaan adat dan kebiasaan Jawa kuno. Bangunan yang indah tersebut merupakan bukti daerah ini mempunyai peran penting dalam sejarah perkembangan agama Budha Indonesia khususnya pada abad kedelapan Masehi (Suripto, jurnal Manusia dan Lingkungan, 2001:38-39).

Candi ini dibangun diatas sebuah bukit kecil, dan terdiri dari sebuah stupa besar di bagian tengah dan tujuh teras yang mencakup seluruh lereng bukit dan membentuk galeri terbuka, dan menghubungkan setiap tangga dan pintu gerbang. Stupa besar di bagian tengah ini memiliki diameter lima puluh meter, stupa besar ini dikelilingi oleh tiga lingkaran yang terdiri dari tujuh puluh dua stupa, dan seluruh bangunan mencapai luas enam ratus dua puluh meter persegi, dan tinggi sekitar seratus meter. Pada dinding teras terdapat tempat yang memuat figur-figur yang duduk bersila dengan ukuran lebih besar dari pada ukuran aslinya dengan jumlah sedikit empat ratus, dan kedua sisi dinding teras yang berupa batu solid diukir dengan relief berupa kerumunan banyak figur (Wallace, 2015:172).

Candi Borobudur dibangun pada abad ke-8 Masehi selama sekitar 75 tahun. Istilah Borobudur berasal dari kata boro yang berarti 'wihara' dan budur yang berarti 'tanah tinggi' atau 'bukit'. Menurut Casparis nama Borobudur berasal dari bunyi prasasti Kahulungan (842 Masehi) "bhumisambara budhara" yang berarti himpunan kebijakan yang bertingkat-tingkat. Selanjutnya 
struktur bangunan candi ini terdiri dari tiga bagian, yaitu kamandhatu (kaki candi) yang menggambarkan alam hidup manusia yang masih dikendalikan hasrat nafsu keduniawian; rupadhatu (badan candi) yang melambangkan masih ada ikatan bentuk materi fisik, dan arupadhatu (lingkaran atas teras candi) yang melambangkan pembebasan manusia dari urusan manusia (Darini, 2013:75).

Bentuk candi Borobudur menyerupai piramida berteras yang dibangun di atas bangunan yang berdenah bujur sangkar dengan penampil di tiap sisinya . kata 'candi' berasal dari nama salah satu dewi di dalam panteon Hindu, Candika. Namun kemudian berubah makna menjadi sumua bangunan kuno, tanpa melihat latar belakang keagamaannya. Galeri prosesi tiga galeri pertama juga memiliki penampil yang mengarah keluar dan memiliki gapura ditiap sisinya (Timur, Selatan, Barat, dan Utara). Gapura masuk ada di sebelah Timur dan begitu melewati gapura pertama pengunjung langsung berada di jalan prosesi mengelilingi candi yang lebarnya 3 meter. Arah jalan keliling memutar ke kanan searah jarum jam sehingga bangunan candi ada di sebelah kanan. Arah putar ke kanan ini merupakan lambang penghormatan kepada kepada dewa dan disebut pradakshina (dakshina artinya kanan, sisi kanan). Arah memutar ke kanan juga sesuai dengan perputaran matahari. Secara simbolis gerak perputaran tersebut bermakna ketidakahiran, totalitas, karena gerak perputaran pada hakikatnya tiada berawal dan tiada berakhir. Hal ini berkaitan dengan hidup, kehidupan, dan kehidupan setelah kematian. Sebaliknya perputaran yang berlawanan dengan arah jarum jam (ke arah kiri) disebut prasawya yang berarti kebalikan dari kehidupan, yakni kematian (Haryono, 2011:6-7).

Candi Borobudur yang tampak megah sekarang ini adalah hasil karya arsitektur nenek moyang bangsa Indonesia yang sangat tinggi nilainya. Nilai-nilai yang melekat pada candi Borobudur terutama nilai pendidikan moral yang terpahatnya dalam bentuk relief ini telah membuktikan bahwa pada zaman dahulu bangsa Indonesia telah mampu membuat karya monumental yang sampai sekarang masih dapat dinikmati. Pada masa kerajaan Mataram kuno kehidupan keagamaan berjalan dengan baik dalam artian tidak terjadi pertentangan antar agama Hindu dan Budha. Kedua agama ini nampak hidup berdampingan dengan damai. Perhatian raja sangat besar terhadap perkembangan serta pertumbuhan agama pada waktu itu. Hal ini dapat dilihat dari banyaknya bangunan keagamaan Hindu maupun Budha, bahkan kedua bangunan candi yang berlatar keagamaan berbeda didirikan berdekatan, misalnya untuk wilayah Magelang candi Borobudur di kelilingi oleh candi-candi Hindu, begitu juga untuk wilayah Selatan misalnya candi Prambanan di kelilingi oleh candi Sewu, Plaosan dan lain-lain (Taufik, 2004:14).

Bangunan klasik Hindu dan Budha di Jawa berkembang pesat, hal tersebut terbukti dengan banyaknya tinggalan yang bersifat monumental. Candi yang tersebar dari daerah Dieng (Wonosobo), Magelang. Di Yogyakarta dan Klaten, banyak yang merupakan candi-candi besar dan raya dengan aneka hiasan. Bangunan tersebut menurut beberapa arkeologi merupakan bangunan yang berfungsi sebagai candi pemujaan. Bangunanan masa klasik tersebut dibangun secara besar-besaran pada abad VII-X Masehi. Bangunan tersebut dimulai dari daerah Jawa Tengah, yang kemudian diteruskan ke Jawa Timur pada abad X-XV Masehi. Mengenal perpindahan ke Jawa Timur, disebabkan karena bencana alam letusan gunung Merapi (Siddhayatra, 1996:10).

\section{Kisah Relief Fauna Pada Candi Borobudur}

Sebagaimana telah diketahui bahwa candi Borobudur dihiasi dengan bermacam 
relief cerita, sejak dari dinding kaki candi yang tertutup hingga dinding pagar langkan tingkat ke-5 candi Borobudur. Secara berturut-turut relief cerita dipahatkan, semua relief tersebut terpilih untuk dipahatkan di candi Borobudur tentunya dengan alasan tertentu. Alasan yang paling jelas berhubungan dengan bangunan suci tersebut adalah bahwa kisah-kisah itu berisikan ajaran keagamaan, ajaran kebijakan yang selayaknya dapat ditiru dan dilaksanakan oleh manusia di dunia. Kisah Jataka-avadana sangat dikenal oleh kalangan pemeluk agama Budha, terutama kalangan Mahayana baik dari Tibet, India, dan Jepang. Jataka adalah kisah tentang sang Budha sebelum dilahirkan sebagai pangeran Siddharta. Intinya berisikan kisah-kisah kebajikan yang telah dilakukan oleh sang Bhodhisttva tersebut sebelum menjadi anak raja Kapilavastu. Di candi Borobudur kedua macam kisah tersebut dipahatkan dalam bentuk relief naratif, namun dalam pemahatan tidak dibedakan antara kisah Jataka dan Avadana.

Panil-panil relief menggambarkan kisah-kisah Jataka dipahatkan bersamaan dengan panil yang memberikan kisah Avadana, kadang-kadang berselingan dan bersebelahan, Jadi di candi itu tidak ada tempat khusus bagi pemahatan satu rangkaian kisah dalam relief, misalnya di dinding bawah agar langkan untuk Avadana, sedangkan di dinding atasnya untuk Jataka. Maka dapat ditafsirkan bahwa pada abd ke 8 Masehi candi Borobudur dibangun, kisah Jataka dan Avadana mempunyai kepopuleran yang sama, sehingga para pemahat relief ceritanya tidak perlu membedakan penempatan panil relief di antara kedua cerita tersebut (Balai Konservasi Peninggalan Borobudur, 2009:6-7).

Keberadaan relief jenis-jenis hewan yang terpahat di dinding candi Borobudur secara implisit menunjukan bahwa beberapa jenis hewan telah dimanfaatkan untuk berbagai keperluan manusia sebelum abad ke VII yaitu jenis-jenis hewan budidaya seperti angsa, kuda, kerbau merpati. Jenis-jenis lainnya seperti, singa, kera lebih banyak mengggambarkan lingkungan di India, terutama lingkungan hutan yang menguatkan gambaran tentang kisah perjalanan sang Budha Gautama di India (Suripto, Manusia dan Lingkungan, 2001:44).

Noerhadi, (2012:1-2) pulau Jawa kaya akan peninggalan-peninggalan purbakala, diantaranya ialah bangunanbangunan purbakala yang biasa disebut candi. Candi-candi ini tersebar di Jawa Tengah dan Jawa Timur. Dinding-dinding candi ini dihiasi dengan relief. Hiasan ini bukan penghias atau pengisi bidang belaka, tetapi melukiskan suatu cerita. Banyak dari mereka yang mempunyai relief. Misalnya candi Loro Jonggrang menggambarkan relief cerita Krsnayana yang terdapat pada langkan candi Ciwa dan diteruskan pada langkan candi Brahma; juga terdapat relief cerita Krsnayana pada langkan candi Wisnu. Pada candi Jago kita temukan juga reliefrelief cerita Krsnayana, Parthayajna dan Kunjarakarna. Pada relief candi induk di Panataran dijumpai relief Ramayana dan Krsnayana. Dan masih banyak candi-candi di Jawa yang mempunyai relief cerita.

Diantara candi-candi di Jawa yang paling menarik perhatian ialah candi Borobudur, tidak hanya tampak dari susunan bangunan akan tetapi juga disebabkan banyaknya pahatan-pahatan reliefnya yang mengisi seluruh permukaan dindingnya dan pagar langkannya Reliefrelief ini ada yang yang merupakan relief cerita, ada pula yang merupakan hiasan saja. Relief yang menggambarkan cerita dibagi menurut adegannya menjadi pigurapigura yang semuanya berjumlah 1460 pigura. Relief-relief yang berupa hiasan dipahat ke dalam pigura-pigura yang masing-masing terpisah dan seluruhnya berjumlah 1212 pigura. Deretan pertama relief cerita itu terdapat pada dinding kaki 
candi yang tertutup. Relief-relief ini terdapat diabadikan dengan foto-foto tidak lama setelah ditemukan oleh J.W. ljzerman pada 1885 , sehingga semua pigura-pigura yang berjumlah 160 dapat dikenal pertama kali oleh Sylvain Levi sebagai penggambaran berlakunya hukum karma menurut kitab suci Mahakarmawibhangga.

Manusia prasejarah menggambarkan dirinya beserta alam kehidupan pada dinding-dinding gua tempat tinggal mereka. Kehidupan itu dilukiskan dalam adegan perburuan binatang. Manusia sebagai pemburu ditampilkan dalam situasi bersifat visual, semua itu merupakan sebuah kisah dari rentetan alam kehidupan. Keadaaan serupa ini kita jumpai juga dibeberapa tempat di Indonesia sebagai tinggalan lama. Semula karya demikian merupakan cetusan manusia terhadap lingkungan, kemudian mengarah pada hubungan manusia terhadap sesuatu yang lebih dari dirinya. Digambarkan manusia sebagai figur dari nenek moyang dan rupanya hal ini menjadi suatu yang turun temurun dilakukan. Ungkapan perasaan demikian ini berlangsung terus, sehingga kita dapat menemukan bagaimana penggambaran nenek moyang ini pun menjadi suatu bentuk ragam hias atas benda-benda yang dibuat di Indonesia. Melihat pada kenyataan demikian, sebenarnya ragam hias yang dibuat dengan teman hidup sebenarnya bukan lagi karena hal yang baru. Eratnya hubungan antara kehidupan dengan nenek moyang ini tampak demikian kuatnya. Kita dapat saksikan bagaimana semua ini merupakan dari budaya; kita melihat di kepulauan Nusantara ini hampir semua suku bangsa menampilkan dalam bentuk karya yang beraneka ragam (Toekio, 1987:112).

Kajian fauna (binatang) dalam arkeologi merupakan salah satu bidang bahasan penting bagi pemahaman masa lalu manusia. Aspek-aspek yang dapat diungkap melalui bidang kajian ini sangat luas cakupannya, meluputi aspek pemanfaatan praktis hingga sakral fauna, baik dalam kehidupan hingga kematian manusia. Ragam jenis fauna yang dimanfaatkan oleh manusia untuk berbagai kegunaan didapat baik dari hasil perburuan maupun domestikasi. Manfaat yang diperoleh manusia dari beragam jenis hewan merupakan cerminan betapa besar ketergantungan manusia terhadap eksistensi fauna dimasa lalu hingga saat ini. Pada awalnya keberadaan fauna hanya dimanfaatkan sebagai salah satu sumber pangan, melalui konsumsi dagingnya, seiring perkembangan kamampuan nalar manusia, fauna juga dimanfaatkan sebagai bahan sandang, melalui bulu atau kulitnya. Pengetahuan empiris manusia selama berintraksi dengan lingkungan hayatinya kemudia berhasil melihat kegunaan lain dari keberadaan jenis binatang tertentu, yakni sebagai sarana trasnsportasi baik sebagai tunggangan maupun pengangkut muatan barang (beban) (Kemendikbud, 2012:1).

Selain manusia yang digambarkan sebagai tokoh diterapkan dalam berbagai bentuk kaya seni, kitapun dapat menjumpai bentuk-bentuk hewan. Keduanya merupakan kelompok dari makhluk hidup yang banyak memberikan sumber penciptaan ragam hias. Kita tahu binatang sangatlah banyak jenisnya, demikian pula dengan yang hidup di Indonesia. Kita dapat bagi kesemuanya itu dalam 3 (tiga) jenis secara garis besar: 1) binatang yang hidup di darat (termasuk binatang melata); 2) binatang yang hidup di air; 3) binatang yang hidup di udara atau bersayap. Dari ketiga jenis itu dapat kita peroleh beriburibu bentuk penggambaran, oleh karena itu tidak mengherankan bahwa setiap jenis dapat memberikan corak yang berlainan. Tentu saja perbedaan ini berlatar belakang pada kemampuan mencipta serta faktor lain yang berkaitan dengan tingkat peradaban. Tidak jarang unsur adat dari kepercayaan itu turut menentukan, misalnya dalam penggambaran benda- 
benda magis atau sejenisnya. Hal seperti ini banyak kita jumpai dibeberapa tempat di Indonesia, dengan bentuk yang memberikan ciri tersendiri. Di Sumatera kita jumpai ragam hias sebagai penangkal berupa Reret (Cecak) dengan bentuk geometris singa-singa, kuda. Di Toraja berupa kerbau (kabong'ngo), kerbau di Poso, naga di Kalimantan serta burung enggang dan harimau. Di Jawa: garuda, ular, ikan serta udang dan banyak jenis lainnya yang bersumber dari binatang yang dekat dengan lingkungan kehidupan masyarakat kita (Toekio, 1987:115).

Dalam perkembangan kebudayaan, manusia selalu akrab dengan fauna yang hidup di sekitar lingkungan hidupnya. Pada gua-gua yang pernah dihuni oleh manusia purba banyak dijumpai gambaran fauna sebagai simbol atau lambang. Fauna yang digambar umumnya adalah fauna yang hidup di daerah sekitar gua. Kemudian relief binatang juga banyak dijumpai pada pahatan dinding-dinding bangunan candi. Pada dinding-dinding candi banyak tersebar di pulau Jawa yang dibangun pada masa yang berbeda, juga banyak dijumpai relief berbagai jenis fauna. Pada dinding candi Borobudur juga banyak dijumpai relief fauna dari berbagai kelompok hewan paling sedikit 25 jenis seperti mamalia, aves, reptilia, dan pisces. Relief yang tergambar pada pahatan dinding candi Borobudur dapat mengungkapkan banyak hal yang berkaitan dengan pengaruh kebudayaan India masa lalu. Tata bangunan candi ini sendiri merupakan hasil perpaduan antara kebudayaan India dan Jawa. Relief-relief pada pahatan dinding candi Borobudur itu jelas berisi tentang kisah perjalanan hidup sang Budha yang berasal dari India (Suripto, Manusia dan Lingkungan, 2001:38).

Manusia prasejarah sudah memberikan bukti kepada kita, bahwa mereka dalam masa kehidupannya banyak mewariskan peninggalan yang terhingga. Seperti apa yang diungkapkan oleh para ahli sejarah, tentang bagaimana kehidupan mereka. Mereka merasakan ada sesuatu yang menarik perhatiannya dalam menggambarkan binatang sebagai cetusan emosinya. Apa yang digambarkan adalah jenis-jenis binatang yang erat hubungannya dengan alam kehidupan saat itu. Keadaan demikian terjadi karena alam kehidupan mereka bersifat perburuan. Peninggalan masa lampau atau zaman prasejarah ini, dapat dijumpai di dinding-dinding gua tempat tinggal mereka (Toekio, 1987:126).

Informasi tentang pemanfaatan hewan oleh masyarakat Jawa pada zaman dahulu sangat miskin, secara umum dinyatakan bahwa sebelum masuk dan berkembangnya pengaruh Hindu dan Budha ke pulau Jawa, nenek moyang kita, selain berburu satwa liar, juga telah mengenal beternak kerbau, sapi, babi, kuda, dan unggas. Bila hal itu benar, maka proses domestikasi pertama kali tidak dilakukan oleh masyarakat pulau Jawa, karena menurut Boyden asal usul domestikasi kerbau dari wilayah Asia Selatan-Indochina, kuda dari wilayah Eropa Tengah, dan unggas (ayam dan itik) dari wilayah Asia Selatan-Indochina. Jadi nampaknya kepandaian beternak itu diperoleh sebelum nenek moyang kita bermigrasi dari daratan Asia ke pulau Jawa (Suripto, Manusia dan Lingkungan, 2001:40).

\section{Relief Singa}

Cerita burung pelatuk dan seekor singa memiliki sumber yaitu kitab Jatakamala pada bagian Satapatta Jataka yang mengisahkan seekor burung pelatuk yang menolong singa tetapi singa tersebut tidak mau membalas kebaikan pelatuk, bahkan menyakitinya. Dalam pustaka Tantri Kamandaka dikisahkan dalam versi agak berbeda pada bagian pelajaran ke XXVII, yaitu kisah harimau tersengkelang tulang manusia atau cerita pelatuk kepada sahabatnya. Di sebuah hutan hidup burung pelatuk yang baik hati. la berbulu indah dan 
tidak mau menyakiti mahluk lain. Oleh karenanya, ia sudah merasa cukup hanya makan bunga, daun, dan buah-buahan. Pada suatu hari, burung pelatuk melihat seekor singa yangsedang kesakitan karena sebatang tulang menyangkut di tenggorokannya. Burung pelatuk memerintahkan singa untuk membuka mulutnya lebar-lebar dan dengan sebatang kayu yang diletakan berdiri tegak diantara rahangnya maka mulut singa akan terbuka. Burung pelatuk akhirnya dapat mengelurkan tulang dari tenggorokan singa dengan patuknya. Suatu saat, burung pelatuk kelaparan dan kebetulan melihat singa yang dulu pernah ditolongnya sedang memakan daging tetapi singa tidak memberinya dan bahkan mengusir burung pelatuk. Burung pelatuk pergi meninggalkan singa tersebut dan tidak menaruh dendang padanya. Meskipun dewa menyarankan agar burung pelatuk mematuk mata singa tersebut agar menjadi buta, tetapi pelatuk tetap tidak mau melakukannya (Balai Konservasi Peninggalan Borobudur, 2009:36). Jenis hewan mamalia singa, dengan ciri tubuh yang khas dengan adanya rambut jumbai sekeliling kepalanya. Jenis hewan ini secarah alami dijumpai di India, namun tidak pernah ada di pulau Jawa. Bila dikaitkan dengan legenda, maka keberadaan singa ini dimaksudkan untuk menjaga tempat suci, sehingga disebut khusus yaitu patung Simha. Relief yang mirip kucing besar termasuk dalam genus Felis. Bila dicermati bahwa relief ini seperti berada dalam setting lingkungan hutan, maka dapat dipastikan bahwa singa tersebut adalah singa liar, karena singa ini berada satu bingkai dengan dua ekor rusa, dan posisi singanya seperti sedang berusaha menagkap rusa tersebut (Suripto, Manusia dan Lingkungan, 2001:42).

Singa sering disebut sebagai raja hutan, walaupun pada kenyataannya binatang ini tidak selalu hidup di dalam hutan. Singa dianggap merupakan raja dari kerajaan binatang. Hal tersebut kemungkinan karena singa tidak mempunyai musuh alami dalam kehidupan mereka. Singa mudah dikenali dari tubuhnya yang berwarna keemasan. Adapun hal yang membedakan antara singa jantan dan betina adalah pada singa jantan terdapat surai disekeliling kepala serta punggungnya. Setidaknya terdapat 12 subspesies singa di seluruh dunia. Singa terbesar hidup di Maroko sampai Mesir yaitu singa Barbary (Panthera leo leo) atau yang lebih dikenal dengan nama singa atlas. Singa jenis ini dapat mencapai panjang 3-3,4 meter.

Sunaryo, (2009:135) motif hias singa datang ke Nusantara bersama dengan kebudayaan Hindu-Buddha. Kemudian pada masa berikutnya, motif hias singa mendapat pengaruh dari bangsa Eropa, melalui lambang-lambang pada panji-panji yang mereka bawa. Di dalam agama Hindu, Durga istri Syiwa sebagai Kali maupun Bhairawi, sering dilukiskan mengendarai singa. Dalam agama Budha, singa adalah binatang suci dan lambang keberanian dan kekuatan. Motif hias singa pada candi Borobudur, selain berfungsi sebagai dwarapala, yakni patung penjaga gerbang masuk candi, juga dipahatkan pada dinding sebagai hiasan. Motif hias singa dalam bentuk relief itu, bagian ekornya bersambung dengan pola pilin yang menjadi motif sulur. Kegemaran menggabungkan ekor binatang dengan motif tumbuh-tumbuhan rupanya berlanjut terus, dan dapat ditemukan pada candi Jawa Timur beberapa abad sesudahnya dalam bentuk hiasan medalion. Bahkan pola hias semacam ini juga dijumpai pada beberapa ornamen di kompks masjid Mantingan Jepara abad ke XVI. Beberapa motif kala, terutama tipe kala klasik awal lebih memperlihatkan wajah singa dari pada muka raksasa.

Di Jawa tumbuh kesenian singa barong dalam pertunjukannya. Reog Panaraga, misalnya, motif kepala singa 
barong digambarkan seperti harimau dengan mahkota bulu merak. Bentuk dasar singa barong yang bermahkota bulu-bulu merak dalam pertunjukan reog ini memiliki kesamaan dengan bentuk kala, yang dari atas dahinya tumbuh pemancar rambut dalam gubahan motif flora. Dalam kepercayaan Hindu, avatara (penjelmaan) Wisnu ialah Narasimha, artinya manusia singa. Patungnya yang seperti raksasa berbentuk manusia berkepala singa tersebut misalnya terdapat di candi ljo, Jawa Tengah. Kadang-kadang motif hias singa, harimau dan anjing agak sulit dibedakan dalam motif hias di Jawa. Bentuk motif hias singa lebih mirip bentuk kilin, patung, binatang penjaga gerbang sebuah kelenteng. Motif singa digunakan untuk antara lain menghias benda upacara dan pusakan, misalnya genta perunggu dan keris. Di Cirebon, motif singa barong dikenakan pada kereta kerajaan, ukir kayu, dan pada batik. Kerajaan Hindu Pajajaran di Jawa Barat menggunakan harimau atau singa putih sebagai lambang kerajaan. Patung singa putih terdapat di gerbang kerajaan Kanoman Cirebon. Motif hias singa sebagai pengaruh Eropa terdapat pada tenun Sumba, di Bali motif singa sering kali digambarkan bersayap.

Lain lagi singa di Cina merupakan sebuah penggambaran simbolik, dalam artian tidak merujuk pada singa sebagai binatang di alam liar. Hal tersebut karena singa bukanlah binatang yang dapat dijumpai di Cina kecuali di datangkan dari India. Seiring dengan perjalanan waktu bentuk dari figur singa tersebut telah dimodifikasi sedemikian rupa sehingga mengasilkan sebuah gambaran singa yang merupakan hasil dari hubungan dengan budaya Persia dengan karakteristik singa salju dari tibet. Sebuah varian yang paling penting dari penggambaran singa adalah diadopsinya gambaran anjing-peking yang dianggap menyerupai singa. Dalam hal ini tentu bukan dalam hal ukurannya. Dan pada akhirnya penggambaran singa sebagai makhluk mitologis di Cina lebih mirip dengan gambaran anjing apabila dibandingkan dengan singa.

\section{Sekumpulan Relief Burung dan Seekor Ikan}

Cerita gambar diatas menunjukan cerita tentang ikan dan kebutuhan akan air hujan, jika dirunut bersumber dari kisah Jatakamala pada bagian Matsya Jataka, yaitu kisah kelahiran Budha yang menjelma pada seekor raja ikan. Kepala kelompok ikan mengetahui bahwa musim kemarau yang panjang telah menyebabkan kekeringan. Raja ikan sangat sedih melihat keadaan itu. la khawatir jika ikan dan binatang-bianatang lainnya akan mati kekeringann. Kepala ikan kemudian memohon kepada yang maha kuasa agar diberi hujan secukupnya, agar ikan-ikan di kolam maupun di sungai masih dapat hidup. Sikap bijaksana kepala ikan tersebut mengetuk hati dewa dan akhirnya mengabulkan permohonannya (Balai Konservasi Peninggalan Borobudur, 2009:27).

Burung merupakan salah satu hewan yang juga banyak digambarkan dalam tradisi megalitik, penggambaran kerap dikaitkan dengan wahana roh ke dalam arwah. Karena sarang burung berada ditempat-tempat yang tinggi maka tempattempat penguburan budaya megalitik juga berada di tempat yang tinggi. Burung juga dijadikan lambang kepemimpinan (Kemendikbud, 2012:165-166). Bahkan perilaku hewan ini kerap dijadikan inspirasi berbagai tarian di dalam masyarakat tradisional. Bagi masyarakat Nias, Tari Moyo (elang) dan tarian untuk perempuan lainnya (saembu, maena, fanali tuwu dan lain-lain) geraknya menggambarkan gerak burung. Biasanya kedua tangan direntangkan ke samping dengan posisi agak tinggi, pada masa lalu tarian ini dikaitkan dengan inisisasi para perempuan, yang telah menguasai tariannya dianggap sudah matang untuk berumahtangga dan 
dapat meningkatkan statusnya di masyarakat sehingga di dalam perkawinan memiliki syarat mahar yang tinggi/besar.

Pada masyarakat Gayo terdapat tarian guel yang merupakan tarian yang menggambarkan aktivitas burung enggang. Konsep tarian seperti ini juga kita temukan pada masyarakat Karo yang disebut gundala-gundala. Burung sebagai salah satu totem, erat kaitanya dengan konsep animisme/dinamisme pada masyarakat tradisional. Pemanfaatan burung enggang sebagai media ritus tertentu sangat mungkin didapatkan dari pengetahuan manusia pada masa prasejarah akan prilaku hewan tersebut. Burung selain dipercaya sebagai sarana roh ke alam arwah, dikaitkan dengan kepemimpinan, digunakan sebagai media penghubung antara dukun dengan roh juga sebagai hewan pelindung satu kelompok. Bahkan bagi beberapa belah di Gayo Lues sebagian jenis burung untuk dimakan. Hal tersebut jelas menunjukan bahwa aspek animisme, dinamisme telah tumbuh subur pada masa lalu di wilayah Tanah Gayo.

\section{Relief Burung Merak dan Angsa}

Motif burung merak sudah dikenal pada nekara peninggalan prasejarah. Burung merak hidup di hutan memiliki bentuk dan warna yang indah. Ekornya yang panjang dan biasanya digambarakan dalam keadaan terbuka dengan pola-pola bulatan pada bulu ekornya itu merupakan ciri yang menonjol. Ciri lain ialah leher yang panjang dan kepalanya berjambul dan ekornya menjuntai ke bawah, tetapi tidak dalam keadaan terbuka. Motif burung merak tergayakan dalam pola geometris. Dalam agama Hindu burung merak dipandang sebagai wahana dewa perang, yakni dewa Skanda atau Kartikeya, juga kendaraan dewi Parwati ibunya. Selain sebagai lambang dunia atas, burung merak lambang kesucian dan kebahagian.

Ornamen pada istana sultan Yogyakarta pada salah satu gapuranya yakni Gapura Agung dihias dengan motif sayap. Motif sayap ini dalam kebanyakan ornamen di Jawa sesungguhnya mewakili motif burung. Pada hiasan relief diatas pintu gapura terdapat motif hias burung merak, dimaksudkan sebagai sangkalan memet. Sedangkan memet ialah tanda titimangsa bergambar. Rupa burung merak dilukiskan berjambul dan berekor panjang itu sedang mengisap sekuntum bunga dalam susunan setangkup menghadap ke arah tengah, sementara dibagian tengah terdapat pokok tanaman bunga yang tumbuh tegak kokoh. Sebagai sangkalan memet, hiasan itu dibaca "Lajering Sekar Sinesep Peksi" yang berarti pokok tumbuhan berbunga yang diisap burung dan bermakna angka tahun 1691 (J). Selanjutnya, angka tahun 1691 sama dengan tahun $1757 \mathrm{M}$, tahun yang menandai pembangunan Tamansari (Sunaryo, 2009:68). Jenis merak (genus pavo) adalah burung dengan ciri yang khas kepala relatif kecil dengan bulu kuncung dikepala dan bulu ekor yang panjang. Genus pavo ini tersebar luas di Asia termasuk pulau Jawa, ini terdiri dari beberapa spesies. Spesies yang hidup di India adalah payo eristatus, sedangkan spesies yang hidup di pulau Jawa adalah pavo mulieus.

Relief selanjutnya yaitu burung seperti merpati adalah anggota genus columba. Anggota genus ini menyebar luas di Asia termasuk India dan pulau Jawa. Bila dikaitkan dengan gambar diatas relief burung tersebut seperti sedang berada di area pintu gerbang rumah, nampaknya nama spesies burung ini adalah columba livia atau merpati, salah satu jenis burung yang sudah lama didomestikasi. Lain lagi dengan jeis burung dengan ciri paruh panjang dan pipin dengan leher relatif sangat panjang termasuk dalam anggota ordo Anse-riformes dan berdasarkan pola bentuk tubuhnya ia lebih tepat masuk familia Anatidae. Burung angsa atau itik tidak pernah di jumpai di pulau Jawa. 
Keberadaannya sekarang di pulau Jawa karena hasil introduksi manusia ( Suripto, Manusia dan Lingkungan, 2001:42).

\section{Relief Rusa}

Rusa termasuk binatang yang telah diabadikan dalam ornamen prasejarah, antara lain adalah nekara perunggu. Rumah suci untuk dewa dalam pura desa di Singaraja, Bali, hiasan dengan motif kepala rusa, untuk mengingatkan pelarian dari Majapahit karena menolak menjadi penganut Islam. Hewan ini dianggap memiliki usia hidup panjang sehingga digunakan sebagai lambang kelestarian. Rusa juga dipahat sebagai hiasan relief pada dinding candi Borobudur, bersama binatang-binatang lain. Sebagai contoh motif rusa pada dua panel relief kaki candi yang menceritakan Karmawibangga. Dalam sebuah panel tampak motif dua ekor rusa saling berhadapan, dan diatas pohon terlihat kera. Pada panel lainnya binatang rusa dipahat di bagian kiri, di dekatnya terpahat binatang lembuh dan kuda. Sedangkan pada gerbang di masjid Sendangduwur, yang terkenal dengan paduraksa bersayapnya, hiasan kala marga yang biasa terdapat di pintu candi digubah menjadi hiasan kala marga di atas pintu gerbang itu pada bagian kiri dan kanan tampak berlanjut dengan motif kepala rusa. Motif hias kala sebagian sudah mengalami kerusakan, tetapi motif kepala rusa masih utuh dan kelihatan jelas.

Salah satu benda upacara keraton Yogyakarta yang disebut dalang terbuat dari emas berbentuk rusa. Dalang atau kijang adalah lambang kegesitan dan kebijaksanaan, terkait dengan kegesitan berpikir, mengambil tindakan, dan keputusan. Motif hias rusa juga dijumpai pada batik, meskipun sering kali bentuknya sangat tergayakan dan bukan sebagai motif yang menonjol. Sebagai contoh di sini ditampilkan motif hias rusa pada batik pesisiran yang digambar lebih realistis. Motif rusa yang digubah dalam pola geometris tampak pada kain tenun Sumba (Sunaryo, 2009:139-140).

Lingkungan alam Sumba Timur yang kaya akan rusa berpengaruh pula dalam tenunan kain. Rusa dengan tanduk yang megah memberikan asosiasi kepada masyarakat akan kebijaksanaan yang dimiliki oleh seorang pemimpin dalam menentukan dan melihat kehidupan bawahannya. Ibarat rusa dapat meloloskan diri dari kepungan manusia maka pemimpinnya pun hendaknya bertindak berani dan bijaksana dalam mengatasi segala kesulitan yang dialami oleh bawahannya. Jadi, motif rusa menyatakan kebijaksanaan dan keagungan yang hendaknya dimiliki oleh seorang pemimpin. Arti motif ini tercermin di dalam ungkapan yang masih hidup di daerah ini. Ungkapan ini berbunyi sebagai berikut "pajangga kadu rahangu, pasara mata mandungu" yang berarti hendaknya tinggi seperti tanduk rusa dan merah seperti mata ular. Pengertian ungkapan ini adalah bijaksana dan berani dalam memimpin bawahannya. Ungkapan lain adalah "na ma paopangu madangu, na ma maringingu harata" yang berartri yang melingkupi yang banyak dan yang melindungi yang berlaksa". Pengertian yang dimaksud adalah sifat suka melindungi bawahnnya (Depdikbud, 1990:54-55).

\section{Relief Kerbau}

Nenek moyang bangsa Indonesia sejak zaman neolitik telah mengenal kerbau sebagai binatang ternak. Di samping kerbau dapat digunakan untuk membantu dalam mengelolah lahan pertanian, binatang itu dahulu juga dipuja sebagai binatang keramat. Oleh karena itu, motif kerbau dalam ornamen Nusantara umumnya digunakan sebagai lambang kesuburan dan dipandang sebagai penolak yang jahat. Bentuk tanduknya yang melengkung indah dihubungkan dengan bulan. Rumah tradisional Toraja dihias dengan tanduk-tanduk kerbau dari hasil 
binatang kurban dalam upacara-upacara yang diselenggarakan yang dirangkai pada tiang. Beberapa sudut bangunan dan dinding luar juga dihias dengan motif-motif kepala kerbau.

Di daerah Sumba, sebuah perhiasan untuk kepala dibentuk seperti tanduk atau bulan sabit yang disebut laba. Di daerah ini, kerbau yang sering disebut babi dede atau babi yang ditinggikan, juga digunakan sebagai binatang kurban yang istimewa untuk upacara penguburan. Secara simbolis daging kerbau kurban dipersembahkan kepada roh orang yang meninggal dan arwah leluhur. Menurut kepercayaan setempat daging kurban itu menjadi bekal makanan bagi roh orang yang meninggal dalam perjalanan ke Parai Marapu dan untuk menjamu arwah leluhur atau keluarganya yang telah lebih dahulu berada di sana. Sebagai lambang kesuburan, kerbau juga melambangkan dunia bawah. Dalam kaitan ini terdapat tenun Sumba yang menggunakan motif kerbau yang di atasnya terdapat motif burung. Kedua motif ini dihubungkan dengan lambang dunia atas dan dunia bawah. Motif hias kerbau jalak pada tenun asli Lampung melambangkan binatang itu sebagai kendaraan untuk arwah nenek moyang di alam akhirat (Sunaryo, 2009:122).

\section{SIMPULAN}

Candi Borobudur memiliki banyak relief sebagai penghias dinding pada pagar langkan. Relief cerita yang menampilkan tokoh utama manusia tetapi ada juga yang menggunakan binatang. Relief cerita binatang mengandung makna sejarah dan pesan moral yang dapat digunakan sebagai sarana pendidikan. Bagaimana deskripsi cerita binatang yang terdapat dalam relief dan bagaimana pesan moral yang dikandungnya. Dalam relief fauan banyak terkandung pesan moral yang bisa diketahui dari sumber Kitab Jatakamala dan sebagian dari Tantri Kamandaka.
Adapun pokok-pokok moral yang terkandung di dalamnya yaitu hidup adalah pengorbanan untuk menolong sesama dengan ikhlas, orang yang tidak tahu balas budi akan mendapatkan balasan yang seimbang dengan perbuatannya, berkhianat terhadap teman akan merugikan diri sendiri, hendaknya tidak memperlakukan orang lain dengan sewenang-wenang, dan kebencian akan lenyap dengan sikap tulus dan sabar.

Keberadaan relief jenis-jenis hewan yang terpahat di dinding candi Borobudur secara implisit menunjukan bahwa beberapa jenis hewan telah dimanfaatkan untuk berbagai keperluan manusia sebelum abad ke VIII yaitu jenis-jenis hewan budidaya. Di dinding candi Borobudur sedikitnya ditemukan 24 jenis hewan yang mengandung nilai sejarah yang dapat dijadikan sebagai sumber pembelajaran sejarah.

\section{DAFTAR PUSTAKA}

Depdikbud. 2013. Candi Indonesia Seri Jawa. Jakarta.

Haryono, Timbul, Dkk. 2011. Sendratari Mahakarya Borobudur. Jakarta : KPG.

Kemendikbud. 2012. Fauna dalam Arkeologi. Medan: Balai Arkeologi Medan.

M. Toekio, Soegeng. 1987. Ragam Hias Indonesia. Bandung: Angkasa.

Munos, Michel Paul, 2013. KerajaanKerajaan Awal Kepulauan Indonesia dan Semenanjung malaysia, Yogyakarta: Media Abadi.

Noerhadi Citra dan Nindia Inda. 2012. Busana Jawa Kuna. Jakarta: Komunitas Bambu.

Purwadi. 2007. Sistem Pemerintahan Kerajaan Jawa Klasik. Medan: Pujakesuma.

Sugiyono. 2007. Memahami Penenlitian Kualitatif. Bandung: Alfabeta.

Sunaryo, Aryo. 2009. Ornamen Nusantara. Semarang : Dahara Prize. 
Taufik, Muhammad, Dkk, 2004. Borobudur Sebuah Mandala?. Yogyakarta: Balai Konservasi Peninggalan Borobudur.

Wallace, Russel, Alfred. 2015. Sejarah Nusantara The Malay Archipelago.Yogyakarta: Indoliterasi.

Berkala Arkeologi. Vol 32 No 1 Mei 2012. Wisata Minat Khusus "Menguak" Kehidupan Masyarakat Jawa Kuno Melalui Relief Candi. Yogyakarta: Balai Arkeologi Yogyakarta.

Konservasi Benda Cagar Budaya, Vol III No 3 Des 2009. Borobudur. Magelang: Balai Konservasi Borobudur.

Siddhayatra, No 21 Nop 1996. Besar Kecilnya Ukuran Relief Borobudur Berkaitan Dengan Tuntutan Arsitektur Ataukah Cerita?. Palembang: Balai Arkeologi Palembang.

Suripto Agus, Bambang. 2001. Relief JenisJenis Fauna dan Setting Lingkungannya Pada Dinding Candi Borobudur (Online) Yogyakarta: Fakultas Biologi Universitas Gajha Mada. Diakses Hari Sabtu, 19 November 2016 Pukul 23.30 WIB. 